\title{
Determination of vanadium in Natural gas using graphite furnace atomic absorption spectrometry (GFAAS)
}

\author{
Suham Tawfiq* \& Abdul Majeed Khursheed ${ }^{* *}$
}

\begin{abstract}
Tuana Khalil Abdulla*
* college of science, Tikrit university, **college of Nursing, Kirkuk university
\end{abstract}

الخلاصة

يعتبر الفناديوم اكثر الفلزات توفراً في النفط الخام ولهذا السبب يتوقع وجودهد في الغاز

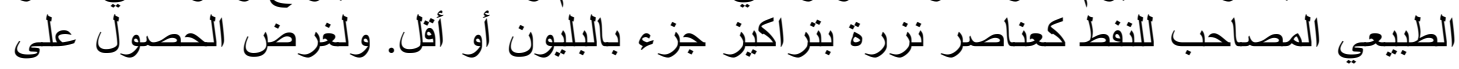

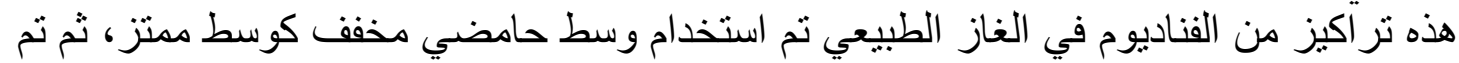

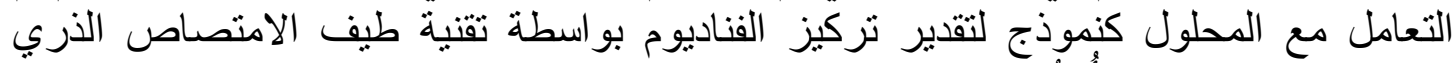

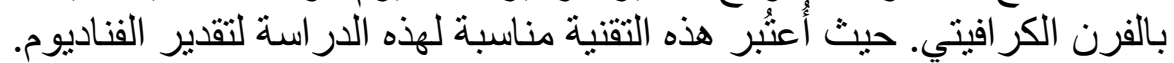

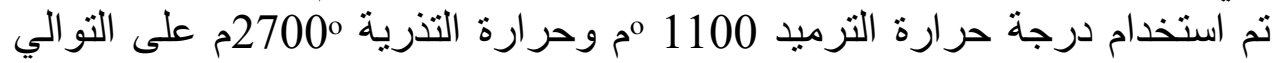

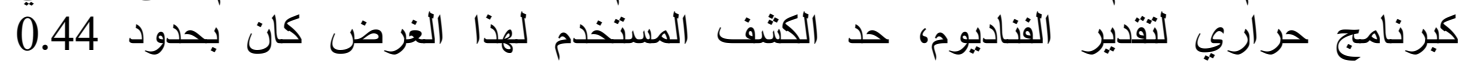

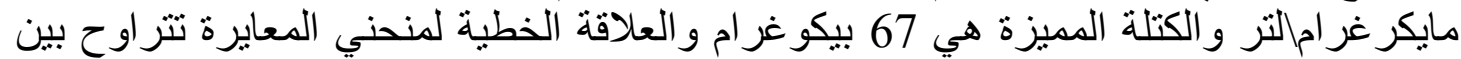

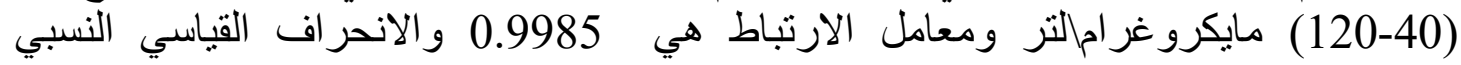

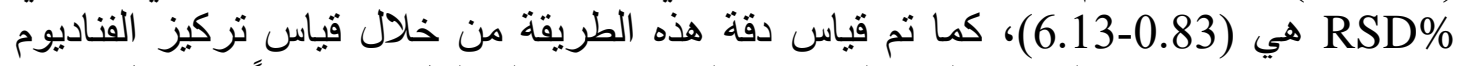

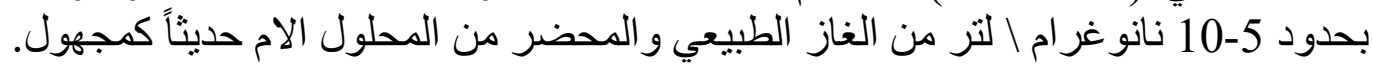

\section{ABSTRACT}

Vanadium is recognized worldwide as the most abundant metallic constituent in petroleum, and this led to expect of its existing in natural gas that associated with oil as a trace amount in ppb concentration or less. For capturing the trace amount of vanadium in natural gas we used diluted acidic medium as adsorption collection, and using the collection medium as a sample. Graphite furnace atomic absorption spectrometry (GFAAS) is the analytical method that utilized in this study to determine (nano-partical) of vanadium. The pyrolysis and atomization temperature used were $1100^{\circ} \mathrm{C}$ and $2700^{\circ} \mathrm{C}$, respectively. This procedure allows determination of vanadium with a detection limit about $0.44 \mu \mathrm{g} / \mathrm{L}$ and characteristic mass of $67 \mathrm{pg}$, the calibration graph was linear in the range (40-120) $\mu \mathrm{g} / \mathrm{L}$ with correlation coefficient of 0.9980 ,

* Presented at the second conference on Chemistry, University of

Mosul, college of Education, 17-18 Novamber-2013. 
and the relative standard deviation RSD\% was (0.83-6.13). the accuracy of this procedure was confirmed by the determination of vanadium in a newly prepared standard solution as unknown concentration. The range of vanadium amount in natural gas supposed to be from 5-10 ng/L .

Keyword : determination of vanadium, adsorption collection medium, GFAAS, chemical modifiers.

\section{INTRODUCTION}

Vanadium is one of the important metal that received extensive attention for determined it in the natural gas, as well as of its determination in crude oil since it is most abundant metals in petroleum and has been evaluated carefully in order to reduce problems during the industrial production process, since it is a catalyst poisoning and causes corrosion $^{(1)}$. Vanadium in trace amount at $\mu / \mathrm{L}$ levels represents as essential element for normal cell growth, but it can be toxic when present in higher concentration ${ }^{(2)}$. The threshold limit values (TLV) reported are $0.5 \mathrm{mg} /$ cubic meter of air. The amount of vanadium in excess of the TLV value is reported to cause dangerous diseases, so the determination of vanadium in environmental and biological sample is highly desirable ${ }^{(3)}$. The vanadium concentration in natural gas proposed to be in $\mathrm{ng} / \mathrm{liter}$. Collecting and detecting the trace element in natural gas cannot be achieved owing to the limits of sampling and detection methods ${ }^{(4)}$. When conducting the ecological geochemistry evaluation of the important natural gas fields, adsorption collection for geogas survey is introduced by researchers for the first time to collect the trace elements in the natural gas, and vanadium was found out successfully as trace elements ${ }^{(5)}$.

A recently published review presents several methods for determination of vanadium in crude oil and petroleum products, such as inductively coupled plasma (ICP)optical emission spectrometry ${ }^{(6)}$, ICP mass spectrometry ${ }^{(7)}, \mathrm{X}$-ray fluorescence spectroscopy ${ }^{(8)}$, and even highperformance liquid chromatography with UV detection ${ }^{(9)}$. By using the technique of graphite furnace atomic absorption which is offering advantages over other techniques since the results from a simple dilution with acidic medium-solvent and ashing were found to be identical ${ }^{(10,11)}$. Stability of metal concentration in sample and calibration solutions might became a serious problem under this conditions ${ }^{(12,13)}$. The use of modifiers became an essential part of electrothermal atomic absorption spectrometry (ETAAS). Modifiers were used in essence since the early days in an effort to gain better control of the conditions in ETAAS. The main purpose of a modifier was at that time and is still today, to bind the analyte element (chemically or physically) in a form so that high enough pyrolysis temperatures could be used in order to remove the bulk of the 
matrix by volatilization or decomposition prior to the atomization of the analyte element ${ }^{(14)}$.

\section{EXPERIMENTAL PART}

\section{1- Apparatus:}

All measurements in this work were carried out using Varian AA240FS graphite furnace atomic absorption spectrometer ( Mulgrave, Australia) equipped with a Varian GTA120 Atomizer unite and Varian programmable sample dispenser PSD 120 auto sampler was used for introduction of the solutions. Hallo cathode lamp for vanadium furnished by Varian were used as a radiation sources, with a current of $20 \mathrm{~mA}$. The main analytical line at $318.4 \mathrm{~nm}$ were used for all determination with a spectral band width of $0.2 \mathrm{~nm}$. deuterium lamp were used as background correction. All experiments were carried out using pyrolytically coated graphite tube without platform (partition tube coated-GTA made in Germany). Argon $99.999 \%$ was used as the purge gas with flow rate $3 \mathrm{~L} / \mathrm{min}$ during all stage except during atomization, were the flow was stopped. Peak height was used exclusively for signal evaluation and quantification . The optimized graphite furnace temperature program used for all determination is given in table 1. In case when chemical modifier was used, the modifier solution was introduced first, and the dry steps of the temperature program were executed in order to dry and "condition" the modifier. Then the program was stopped and the furnace allowed cooling before the sample was introduced, and the entire temperature program executed. The system were controlled by SpectrAA software program from Agilent Technologies installed on window XP operating system.

Table 1. graphite furnace temperature for the determination of vanadium.

\begin{tabular}{|c|c|c|c|c|c|c|}
\hline \multirow{2}{*}{ Step } & $\begin{array}{c}\text { Temp } \\
\left({ }^{\circ} \mathrm{C}\right)\end{array}$ & Time $(\mathrm{s})$ & $\begin{array}{c}\text { Flow } \\
(\mathrm{L} / \mathrm{min})\end{array}$ & Gas Type & Read & $\begin{array}{c}\text { Signal } \\
\text { Storage }\end{array}$ \\
\hline \multirow{3}{*}{ Dry } & 85 & 5 & 3 & Normal & No & No \\
\cline { 2 - 7 } & 95 & 25 & 3 & Normal & No & No \\
\cline { 2 - 7 } & 120 & 10 & 3 & Normal & No & No \\
\hline \multirow{3}{*}{ pyrolysis } & 1200 & 5 & 3 & Normal & No & No \\
\cline { 2 - 7 } & 1200 & 1.7 & 3 & Normal & No & No \\
\cline { 2 - 7 } & 1200 & 2 & 3 & Normal & No & No \\
\hline \multirow{3}{*}{ cooling } & 200 & 8.8 & 3 & Normal & No & Yes \\
\cline { 2 - 7 } & 200 & 2 & 0 & Normal & Yes & Yes \\
\hline \multirow{3}{*}{ atomization } & 2700 & 1.2 & 0 & Normal & Yes & Yes \\
\cline { 2 - 7 } & 2700 & 2 & 0 & Normal & Yes & Yes \\
\cline { 2 - 7 } & 2700 & 2 & 3 & Normal & No & Yes \\
\hline
\end{tabular}




\section{2- Reagents:}

Analytical grade reagents were used throughout. Distilled deionized water (DDW) with a specific resistivity of $0.07 \mu \mathrm{S} / \mathrm{cm}$, from Milli-Q water purification system (TKA smart2pure,made in Germany) was used for the preparation of standards. All containers and glasses ware were soaked in $10 \%$ nitric acid for at least $24 \mathrm{~h}$ and rinsed three times with DDW before use. The aqua stock solution of vanadium $(1000 \mathrm{mg} / \mathrm{L})$ was prepared from ammonium monovanadate in $0.5 \mathrm{~mol} / \mathrm{L}$ nitric acid ( Density $=1.01 \mathrm{~g} / \mathrm{cm}^{3}$ ) the working standards were prepared by serial dilution of the stock solution with DDW. Chemical modifiers are illustrated in table 2 .

Tabel 2. Details of chemical modifier

\begin{tabular}{|c|c|c|c|}
\hline matrix modifier & Concentration & Dissolved in & Manufacture \\
\hline $\begin{array}{c}\text { Palladium as } \\
\mathrm{Pd}\left(\mathrm{NO}_{3}\right)_{2} .2 \mathrm{H}_{2} \mathrm{O}\end{array}$ & $\begin{array}{c}1000 \mathrm{ppm}, \\
3000 \mathrm{ppm}\end{array}$ & $5 \mathrm{M} \mathrm{HNO}_{3}$ & $\mathrm{BDH}$ \\
\hline $\begin{array}{c}\mathrm{Magnesium} \text { nitrate } \\
\mathrm{Mg}\left(\mathrm{NO}_{3}\right)_{2} 6 \mathrm{H}_{2} \mathrm{O}\end{array}$ & $2000 \mathrm{ppm}$ & $0.6 \mathrm{M} \mathrm{HNO}_{3}$ & Merck \\
\hline $\begin{array}{c}\text { Palladium/magnesium } \\
\text { nitrate }\end{array}$ & $\begin{array}{c}3000 \mathrm{ppm} \\
\mathrm{Pd} / 2000 \mathrm{ppm} \\
\mathrm{Mg}\left(\mathrm{NO}_{3}\right)_{2}\end{array}$ & $5 \mathrm{M} \mathrm{HNO}_{3}$ & $\mathrm{BDH} / \mathrm{Merck}$ \\
\hline $\begin{array}{c}\mathrm{L}-(+) \text {-ascorbic acid } \\
\text { powder }\end{array}$ & $10000 \mathrm{ppm}$ & Deionized water & Merck \\
\hline
\end{tabular}

3- Preliminary analysis of the detection result of trace element in natural gas

Figure 1 shows schematic diagram of collection installation of natural gas that installed in one of the feed gas point (natural gas ) in production unite related to North gas company/Kirkuk city/Iraq, which has 406 psi pressure of natural gas separated from all condensate that associated with the natural gas. The system is consist of 1200 psi regulator to control the high pressure of natural gas and it supported by Millipore filter to prevent coarse particles passing through the regulator followed by flow meter that controls the flow rate of the gas in the rate of $1.5 \mathrm{~L} / \mathrm{min}$ through the adsorption liquid (3\% nitric acid). Diluted nitric acid $3 \%$ prepared from concentrated nitric acid ( Wagtach, $1.42 \mathrm{gm} / \mathrm{L}$ ) with ultrapure water. Nitric acid was favored over other liquid medium as it collected the elements well, is easy to purify and is an ideal medium for analysis directly by GFAAS which make detection more reliable and avoid the annoying digestion previously used for solid collector ${ }^{(15,16)}$, one liter nitric acid was distributed in three glass scrubbers so that it could capture as much as possible amount of vanadium particles. After the scrubbers there is second flow meter supported with a counter to calculate 
the whole volume of natural gas in liter passing through the system, here the total quantity is 1200 liter of nature gas through the liquid medium. Each unit links with clear polyvinyl laboratory tube.

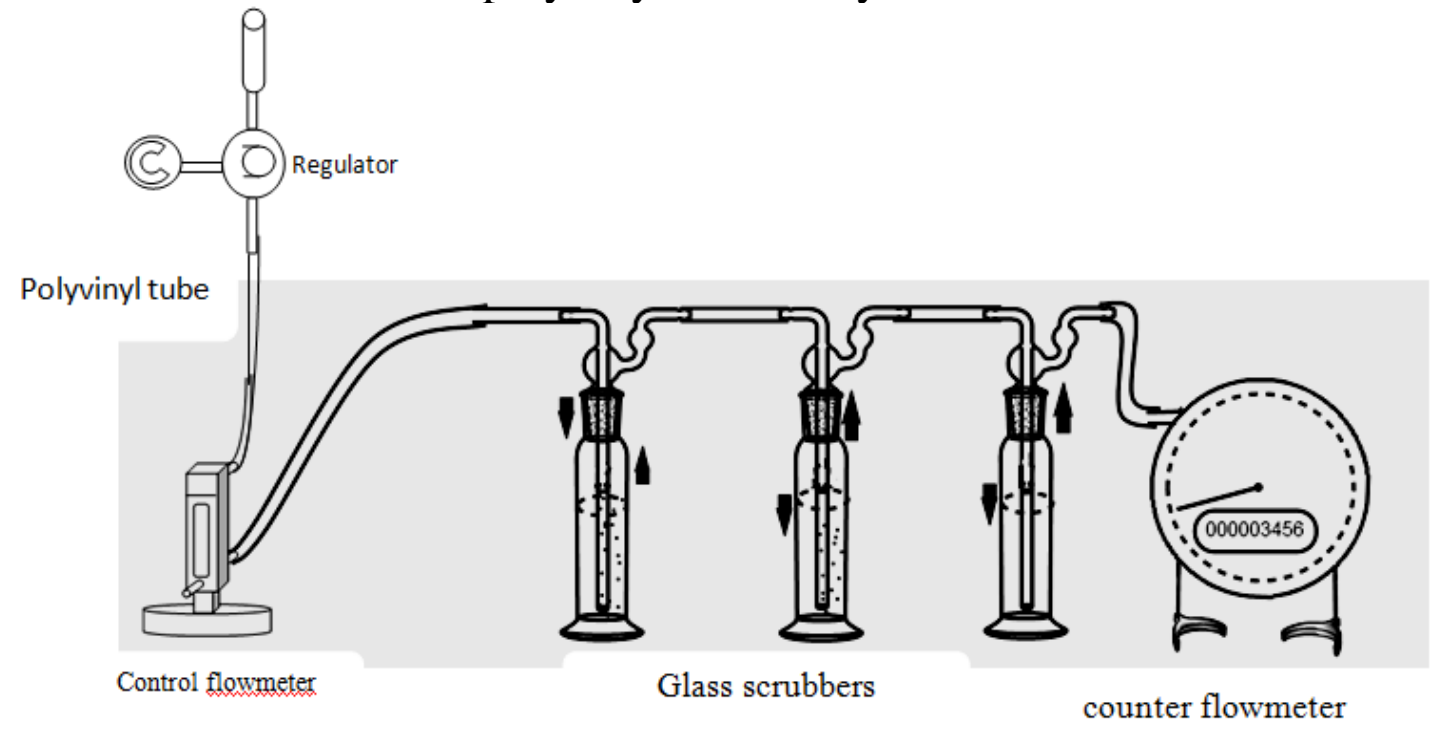

Figure 1. schematic diagram of collection installation of natural gas.

\section{CHEMICAL MODIFIERS}

Three kinds of chemical modifiers were used to choose the maximum permissible pyrolysis temperature, magnesium nitrate has been proposed as a modifier for vanadium ${ }^{(17)}$. By using this modifier with volume equal to the sample volume , $15 \mu \mathrm{l}$ of magnesium nitrate with $15 \mu \mathrm{L}$ of the sample. $2 \mathrm{ml}$ ascorbic acid $(10 \mathrm{~g} / \mathrm{L})$ added to $10 \mathrm{ml}$ of the sample throughout as reduced agent. By using this two modifiers the results were not desirable, magnesium nitrate, shows relatively low signals comparing with Palladium.

Palladium has also been proposed as chemical modifier for vanadium $^{(19,20,21)}$ because it has been used successfully for a large numbers of elements. $15 \mu \mathrm{L}$ of the Palladium solution was dispensed into the graphite tub, followed by $15 \mu \mathrm{L}$ of the vanadium solution, calibration curve were constructed by standard solution containing $(40,60,80,100$ and $120 \mathrm{ppb}$ vanadium stock solution).

By using the mixture of equal volume of both palladium modifier $3000 \mu \mathrm{g} / \mathrm{L}$ and magnesium nitrate $2000 \mu \mathrm{g} / \mathrm{L}$ the results were reasonable and the mixture modifier solution could be reliable, figure 2 . Shows the signal graphics for

$120 \mathrm{ppb}$ vanadium stock solution when using modifier in the previous three state mentioned. 
(a)

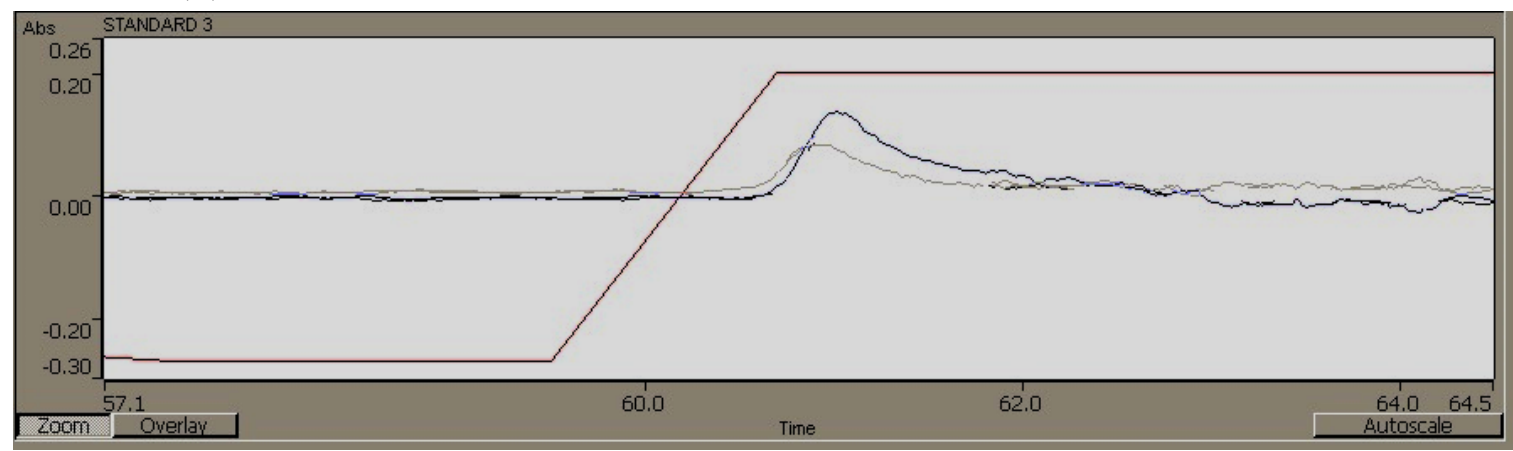

(b)

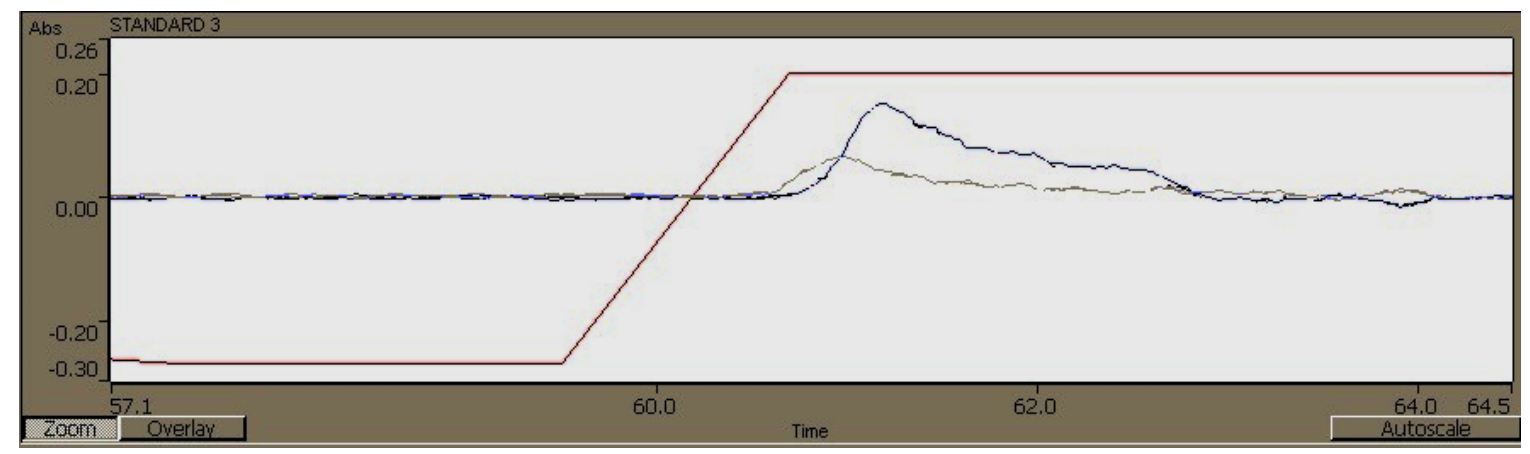

(c)

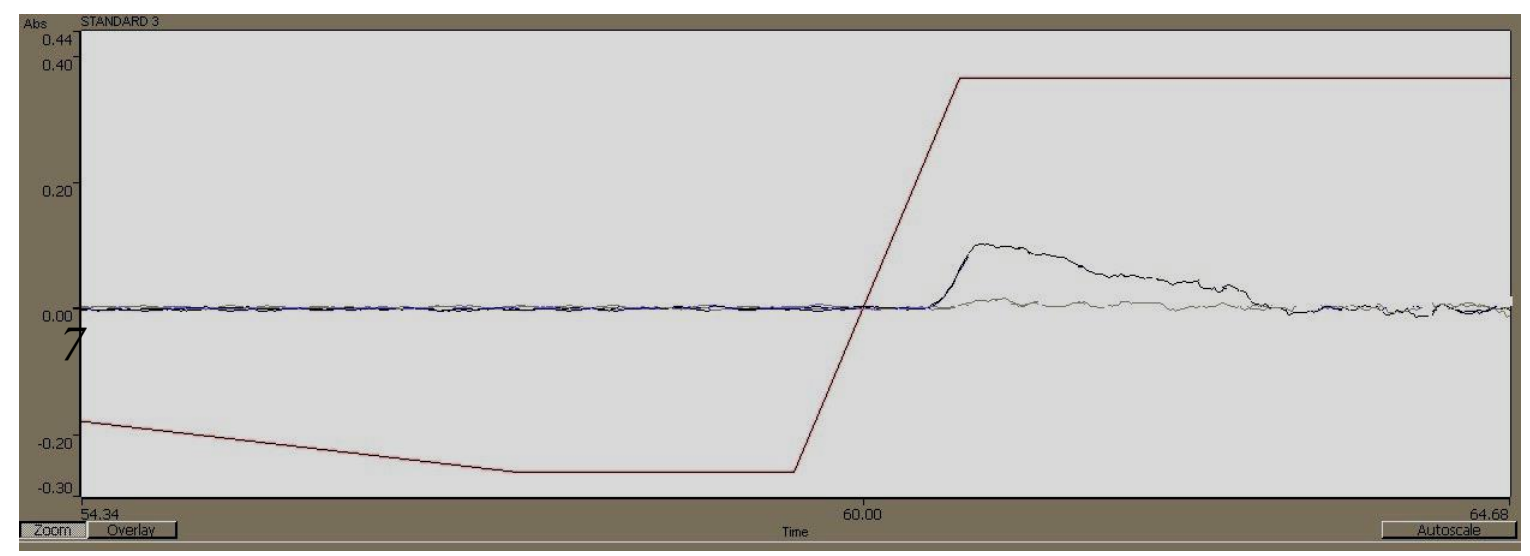

Figure 2. (a) signal graphic for 120ppb vanadium with Palladium modifier, (b) with mixture modifier (Palladium+Magnesium nitrate ) and (c) with magnesium nitrate .

\section{1-Pyrolysis and atomization temperature}

\section{RESULTS AND DISCUSSION:}

The pyrolysis and atomization temperature curves are illustrated in figure 3 those constructed by using $15 \mu \mathrm{L}$ vanadium standard solution $80 \mathrm{ppb}$ and using palladium nitrate as modifier solution. In case of absence chemical modifier more than $70 \%$ of the total concentration could be lost, this was investigated by injecting $80 \mathrm{ppb}$ vanadium standard solution and the instrument reading was just $25 \mathrm{ppb}$. 
Determination of vanadium in Natural gas using graphite furnace....

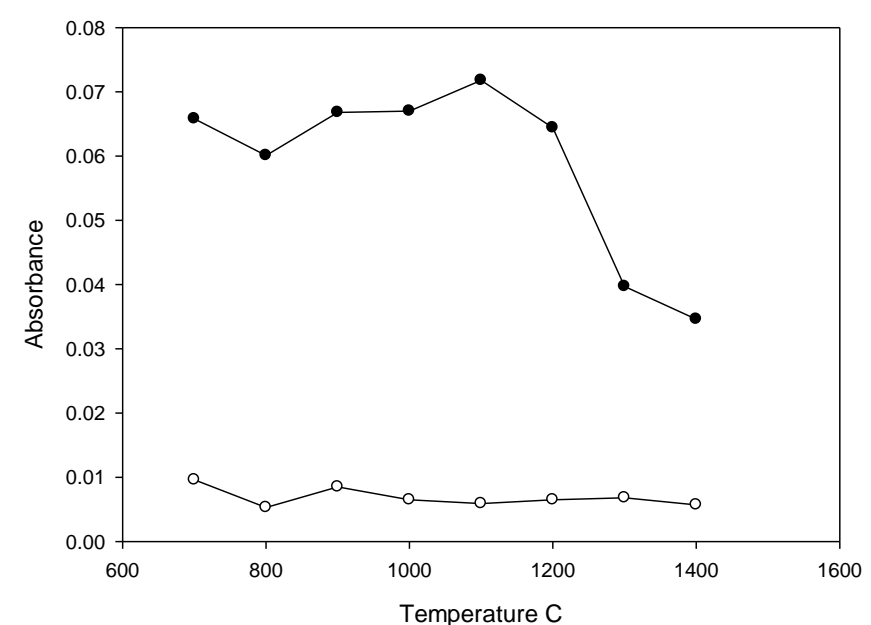

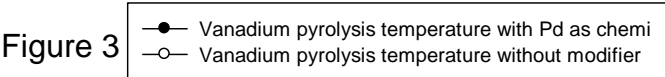

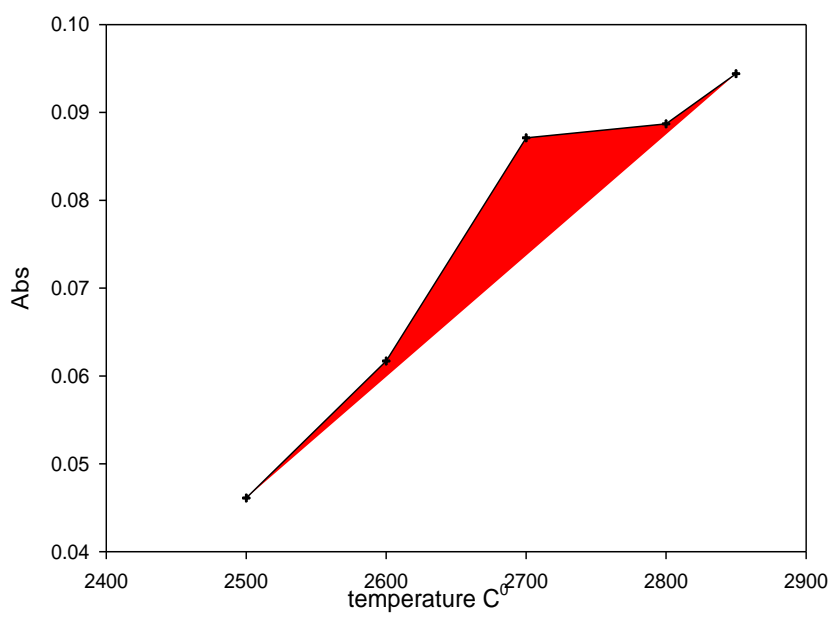

vanadium atomization temperature with palladium as chemical modifie

\section{2- Figure of merits:}

A linear calibration graph was obtained (figure 4) for concentrations (40-120) $\mu \mathrm{g} / \mathrm{L}$ vanadium stock solution in the presence of $\mathrm{Pd}$ modifier, the detection limit of vanadium was found about $0.44 \mu \mathrm{g} / \mathrm{L}$. the calibration graph has correlation coefficient of 0.9985 and relative standard deviation RSD\% between (0.83-6.13) table 3 ..

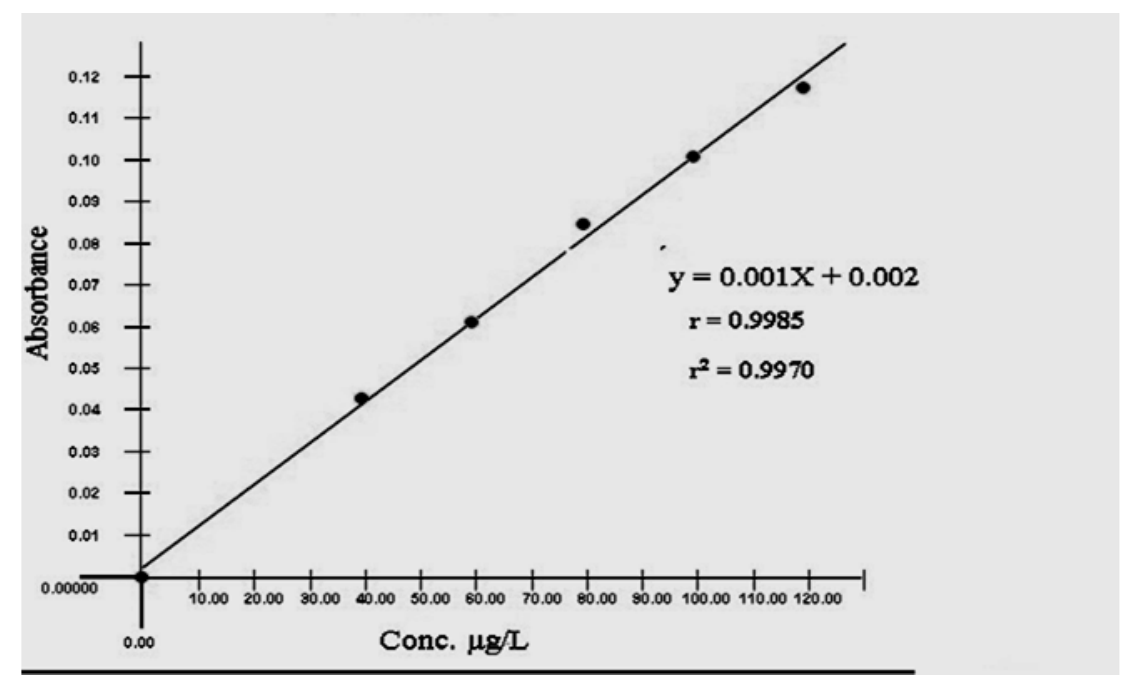

Figure 4. calibration curve for vanadium

table 3: analytical characteristics of vanadium calibrant solution for the proposed method.

\begin{tabular}{|cc|}
\hline Species & Values \\
\hline Calibration & Absorbance $=\mathbf{0 . 0 0 1}( \pm \mathbf{0 . 0 0 0 0 2 8})[\mathrm{V}]+\mathbf{0 . 0 0 2}( \pm \mathbf{0 . 0 0 2 2})$ \\
Linear analytical range $(\mu \mathrm{g} / \mathrm{l})$ & $\mathbf{0 . 4 4 - 1 2 0} \boldsymbol{\mu \mathrm { g } / \mathrm { l }}$ \\
$\mathrm{RSD} \% \mathrm{~N}=\mathbf{3}$ & $\mathbf{( 0 . 8 3 - 6 . 1 3 ) \%}$ \\
LOD $(\mu \mathrm{g} / \mathrm{l})$ & $\mathbf{0 . 4 4}$ \\
\hline
\end{tabular}


[V] expressed in $\mu \mathrm{g} / \mathrm{l} ; \mathrm{N}$ number of measurements

Table 4 is the summarized of the accuracy and precision of the method.

Table 4: accuracy and precision of the method

\begin{tabular}{|c|c|c|c|c|}
\hline Conc. ppb & $\begin{array}{l}\text { Abs in } 3 \\
\text { replicate }\end{array}$ & RSD\% & Erel\% & \% recovery \\
\hline 40 & $\begin{array}{l}\mathbf{0 . 0 4 2 3} \\
\mathbf{0 . 0 4 5 2} \\
\mathbf{0 . 0 4 0 0}\end{array}$ & 6.13 & 7.00 & 107 \\
\hline 60 & $\begin{array}{l}0.0582 \\
0.0610 \\
0.0633\end{array}$ & 4.20 & 2.21 & 102.2 \\
\hline 80 & $\begin{array}{l}0.0840 \\
0.0833 \\
0.0847\end{array}$ & 0.83 & 5.6 & 105.6 \\
\hline 100 & $\begin{array}{l}0.0995 \\
0.0986 \\
0.1020 \\
\end{array}$ & 1.76 & 0.93 & 100.93 \\
\hline 120 & $\begin{array}{l}0.1172 \\
0.1160 \\
0.1152\end{array}$ & 0.87 & -2.5 & 97.5 \\
\hline
\end{tabular}

$\mathrm{t}$-calculated at confidence level $95 \%=1.23$

$\mathrm{t}$ - tabulated at confidence level $95 \%=4.3$

the analytical condition is illustrated in table 5.

Table 5: analytical condition for vanadium determination.

\begin{tabular}{|c|c|}
\hline Calibration Mode: & Concentration \\
\hline Measurement Mode: & Peak Height \\
\hline Wavelength: & $318.5 \mathrm{~nm}$ \\
\hline Slit Width: & $0.2 \mathrm{~nm}$ \\
\hline Lamp Current: & $20.0 \mathrm{~mA}$ \\
\hline Background Correction: & BC On \\
\hline Calibration Algorithm: & Linear Origin \\
\hline
\end{tabular}

The correlation coefficient $\mathrm{R}$ and characteristic mass in pigogram obtained for vanadium using standard solution in $80 \mathrm{ppb}$ concentration and characteristic concentration in $\mu \mathrm{g} / \mathrm{L}$ for all assays that deal with previous chemical modifiers, are given in table 6. The precision expressed as the relative standard deviation of three replicate determinations of the stock solution, prepared sample contain 7.50ng/L vanadium as average. 
Determination of vanadium in Natural gas using graphite furnace....

Table 6. Analytical figure of merits for determination of $\mathrm{V}$ in natural gas

\begin{tabular}{|c|c|c|c|c|}
\hline Analyte & Modifier & $\mathrm{R}$ & $\mathrm{m}^{\circ}(\mathrm{pg})$ & $\begin{array}{c}\text { Characteristic } \\
\text { concentration } \\
\mu \mathrm{g} / \mathrm{L}\end{array}$ \\
\hline $\begin{array}{c}\text { Vanadium } \\
\text { stock } \\
\text { solution }\end{array}$ & $\mathbf{P d}+\mathbf{\text { ascorbic acid }}$ & $\mathbf{0 . 9 9 8 0}$ & $\mathbf{6 7 . 6}$ & $\mathbf{4 . 4 2 9}$ \\
\hline $\begin{array}{c}\text { Vanadium } \\
\text { stock } \\
\text { solution }\end{array}$ & $\begin{array}{c}\mathbf{M g}\left(\mathbf{N O}_{3}\right)_{2}+\text { ascorbic } \\
\text { acid }\end{array}$ & $\mathbf{0 . 9 9 9 1}$ & $\mathbf{8 7}$ & $\mathbf{5 . 4 3 3}$ \\
\hline $\begin{array}{c}\text { Vanadium } \\
\text { stock } \\
\text { solution }\end{array}$ & $\begin{array}{c}\mathbf{P d +} \\
\mathbf{M g}(\mathbf{N O})_{2}+\text { ascorbic } \\
\text { acid }\end{array}$ & $\mathbf{0 . 9 9 9 6}$ & 57 & $\mathbf{0 . 9 2 4}$ \\
\hline
\end{tabular}

$\mathrm{m}^{\circ}$ : Characteristic mass

The absorbance reading for 15 ul sample prepared by passing 1200 liter natural gas in 1 liter diluted nitric acid, and with the use of $\mathrm{Pd} /$ ascorbic acid and the concentration for every signal is illustrated in Table 6. The amount of vanadium supposed to be in $3 \%$ nitric acid is approximately $2 \mu \mathrm{g} / \mathrm{L}$.

Characteristic concentration: this term is expressed as the concentration of an element in milligrams per liter $(\mathrm{mg} / \mathrm{L})$ required to produce a $1 \%$ absorption (0.0044 absorbance) signal.

Char Conc. $(\mathrm{mgL})=\underline{\text { Conc } . ~ o f ~ S t d . ~}(\mathrm{mg} / \mathrm{L}) \times 0.0044$

measured absorbance

Characteristic mass(m: The mass in pigogram of the analyte element producing an integrated absorbance of 0.0044 signal, it's theoretical calculation of sensitivity.

Table 7. Vanadium concentration for the samples after passing 1200 lintr natural gas.

\begin{tabular}{|c|c|}
\hline $\begin{array}{c}\text { Concentration } \\
\mu \mathrm{g} / \mathrm{L}\end{array}$ & $\mathrm{Abs}$ \\
\hline 8.00 & 0.0050 \\
\hline 8.96 & 0.0088 \\
\hline 12.1 & 0.0121 \\
\hline 14.3 & 0.0140 \\
\hline
\end{tabular}

So the amount of vanadium in one liter of natural gas obtained by dividing the concentrations in the table (7) by 1200 after abstracting the $\mathrm{V}$ amount in nitric acid is:

\begin{tabular}{|c|c|}
\hline \multicolumn{2}{|c|}{$\begin{array}{c}\text { Vanadium concentration in } \mathrm{ng} / \mathrm{L} \text { of natural } \\
\text { gas }\end{array}$} \\
\hline Maximum & 10.25 \\
\hline Minimum & 5.00 \\
\hline Average & 7.33 \\
\hline
\end{tabular}




\section{CONCLUSION}

By using graphite furnace atomic absorption spectrometry with deuterium lamp background correcting it was possible to determine the nano-partical concentration of vanadium in natural gas feeds north gas company/Kirkuk city/Iraq, owing to the reason of concerning the vanadium one of refractor elements that make refractory carbides in the graphite furnace, we used pyrolytical coated tube to overcome this problem, and using appropriate chemical modifier for more sensitivity and to suppressing interferences. comparing between several kind of chemical modifiers achieved to have appropriate signals for the target.

\section{REFERENCES}

1) Amorim F., Welz B., Costa A. , Lepri F., Goreti M., Vale R., Ferreira S. (2007), Talanta,68,349-359.

2) pyrnynska k. (2005), Microchem Acta,149,159-268.

3) Kiran T. Kumar and Revanasiddappa H. (2005), Iranian Chemical Society J., 2, 161-167.

4) Duyck C., Miekeley N., Porto dasilveira C., Szatmari P. (2002), Spectrochimica Acta,Part B,1979-1990.

5) Duoyi W., Meizhou D., Yinghan L., Yawei L., Xingyun Li., Renqi L. (2008), Earth Science Frontiers,15,124-132.

6) Aydin I., Aydin F., Hamamci C.,(2013), Microchemical J.,108,6467.

7) Bednar A. (2009) Talanta,78, 453-457.

8) Mandiwana K. L. and Panichev N. (2004), Analytica Chimica Acta,517, 201-206.

9) Khuhawar M. and Arain G. (2006), Talanta, 68, 535-541.

10) Bruhn C. C. (1983), Analytica Chimica Acta,147, 193-203.

11) Bermejo-Barrera P., Pita-Calvo C., Bermejo-Martinez F. (1991), Anal. Lett.,24, 447-458.

12) Aucelio R. Q., Doyle A., Pizzorno B. S., Tristao M. L. B., Campos R. C. (2004),Microchem. J.,78, 21-26.

13) Vale M.G.R., Damin I.C.F., Klassen A., Silva M.M., Welz B., Silva A.F., Lepri F.G., Borges, D.L.G. (2004), Microchem, J.77,131-140.

14) welz B., Schlemmer G. and Jayateerth R. (1992), analytical atomic spectrometry, 7, 1257-1270.

15) Wang M., Gao Y. \& Lin Y. (2008) Geochemistry: Exploration Environments analysis, 8, 183-190.

16) Wang M., Gao Y. \& Lin Y. (2007), B.Milkereit, 83, 993-996.

17) Hill J., Dawson B., john Price W., Shuttler L., Smith M. and Tyson F. (1999), analytical atomic spectrometry, 14, 1245-1285. 
18) Bermejo Barrera P., Beceiro Gonzalez E., Bermejo Barrera A. (1990), Analytica Chimica Acta , 236, 475-477.

19) F'abio A., Welz A., Costa A., Lepri F.G., Maria Goreti R., Ferreira L. (2007), Talanta, 72, 349-359.

20) Damin C., Maria Goreti R., Silva Marcia M., Bernhard Welz G., Fabio N. Walter dos Santos and Sergio Ferreira L. C. (2005), Analytical Atomic Spectrometry, 20, 1332-1336.

21) Maria Goreti R., M'arcia M., Isabel C., Filho P. , Welz B. (2008) Talanta, 74, 1385-1391. 